\title{
DOSSIÊ
}

\author{
Joan Fontcuberta
}

Tradução de Luiza Rabello

\section{A pós-fotografia explicada aos macacos}

\section{Resumo}

O artigo discute como as máquinas estão cada vez mais independentes do humano e atuam sem a nossa mediação, de forma que adquirem a sua própria autonomia, como os GPS, os smartphones e todos os tipos de computadores. Tais mudanças fizeram com que nos dissolvêssemos nelas, sentindo e pensando com elas. Neste contexto, como se posiciona a fotografia que historicamente procurou salvaguardar a identidade e a memória? Isto geraria a dessubjetivação da imagem? Como ficam as conexões entre a autoria, a criação e a nossa condição humana?

\section{Palavras-chave}

Pós-Fotografia. Autoria. Memória. Tecnologia digital. 
Nota do Editor. Artigo também publicado no catálogo da 4ta Trienal Poli/Gráfica de San Juan: América Latina y el Caribe, com o tema Imágenes desplazadas/ Imágenes en el espacio, San Juan, Puerto Rico, 24/10/2015 a 28/02/2016, com curadoria de Gerardo Mosquera, Vanessa Hernández Gracia e Alexia Tala.

\section{O OLHO DO ANIMAL}

No verão de 2014 eu estava em Londres e no interior de um vagão do metrô havia um chamativo slogan publicitário. A manchete era: "Este macaco roubou nossa câmera". A imagem mostrava o retrato de um macaco que, presumia-se, com um ostensivo sorriso celebrava a travessura. Na linha seguinte vinha a explicação: "Quando as coisas vão mal, é necessário um seguro que vá bem". Descobríamos, então, que o anunciante era uma companhia de seguros. Achei a estratégia publicitária chocante e tentei me colocar na pele do criativo que a planejou. Não me recordo de ter visto um macaco viajando no metrô e muito menos que atue como um batedor de carteiras de viajantes como suas vítimas em potencial. É possível que a Travel Insurance ofereça um seguro específico para furtos cometidos por macacos, mas se alguém visita o país dos macacos ladrões, certamente os macacos serão a última coisa para realmente se preocupar. Mas como as viagens no metrô convidam a distrações, me pus a averiguar se por trás de excentricidade do anúncio publicitário, justificável para chamar a atenção, sobressaía alguma outra razão.

Que interesse pode ter um macaco em roubar uma câmera? O que faria com ela? Macacos podem tirar fotos? A questão nem é uma boutade e nem trivial. Implica questões de natureza filosófica em muitos de seus registros. Para começar, isso nos confronta com a questão de se os macacos possuem uma Inteligência que vai além da simples habilidade do manuseio de um instrumento - a câmera - e se são capazes de imprimir intenção consciente a esse ato. Isto é, que existe uma vontade de experiência da imagem.

Se por inteligência se entende o que Jean Piaget definiu como a capacidade de se adaptar ao ambiente, é óbvio que até as baratas e as moscas são inteligentes. Mas a questão se torna muito mais complexa se por inteligência se entende a capacidade de interagir com a realidade em termos abstratos. A etologia cognitiva se ocupa do estudo das capacidades mentais dos animais referentes a mecanismos neuropsicológicos mediante os quais seu cérebro processa a informação que recebe através dos sentidos. Os animais mais "inteligentes" aprendem por imitação, pelo método de ensaio e erro e por repetição. Com esses métodos, adquirem formas de respostas a diferentes situações que vão além do repertório dos reflexos e do instinto. Mas ainda é prematuro 


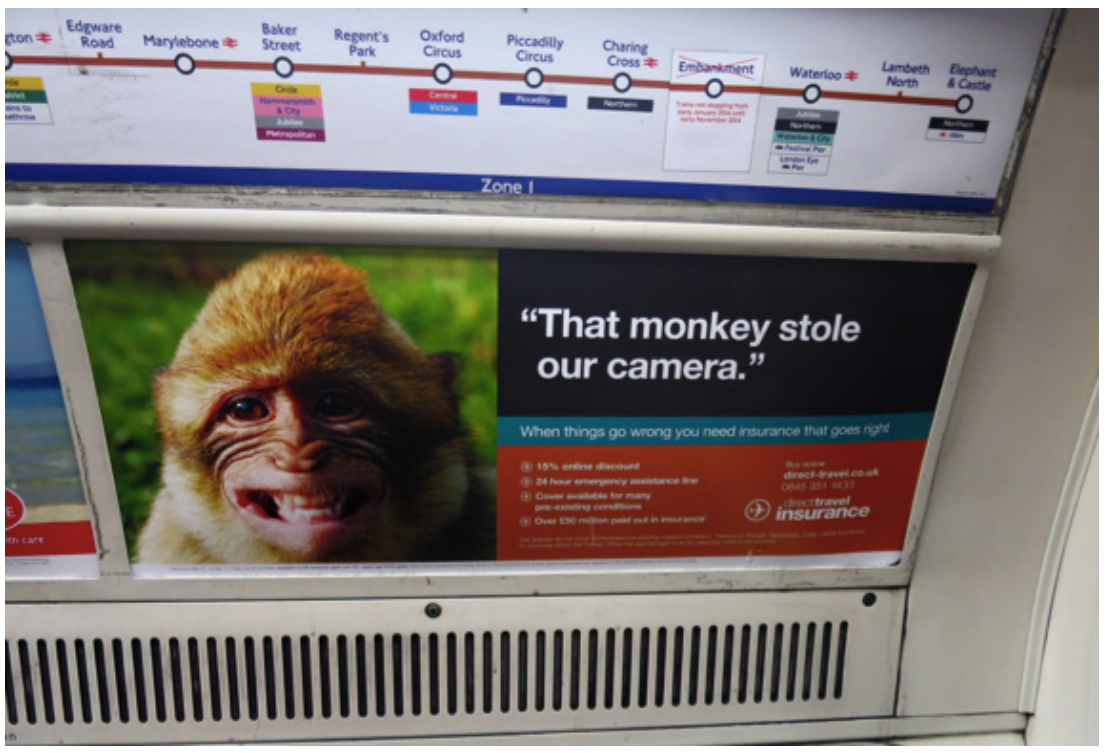

identificar cognição com inteligência. Poderíamos concordar que o ingrediente que falta é a articulação da linguagem, uma codificação de sinais abstratos que permitem a comunicação.

Primatólogos como Franz de Waal e linguistas como Derek Bickerton se referem a "política do chimpanzé": os machos alfa monopolizavam as fêmeas pela força, mas os beta os enganavam estabelecendo alianças políticas. Para isso, necessitavam gerar uma linguagem com categorias de tempo e espaço que Ihes permitia coordenar, burlar os alfa e revezar o acesso às fêmeas. Dessa hipótese, os etólogos concluem que a origem da linguagem se encontra na gestão da pulsão sexual a da consequente necessidade de aumentar a diversidade genética do bando. Outra ilustre primatóloga, Jane Goodall, nos oferece, no entanto, outra saborosa versão. Todo o código dos primatas, argumenta Goodall, já se encontra na relação entre mãe e filho: carinhos, abraços, tapas, piscadelas, caretas... um repertório de gestos com significados precisos. Os olhos se agarravam no pelo de suas mães que os transportavam. Quando a evolução fez os hominídeos perderem os pelos do corpo, as mães tiveram que deixar seus filhos retornarem ao solo para buscar alimento e, por isso, foram levadas a desenvolver uma linguagem com abstração para se comunicarem e protegê-los.

Consideremos plausíveis ou não estas explicações, o que está por trás de toda a dúvida é que a inteligência e todo o pacote consequente (adaptação, abstração, comunicação, expressão...) chega através da evolução lenta dos nossos ancestrais símios. É provável então que, no seu próprio ritmo e pausa, os macacos também adquiram inteligência e, portanto, se dermos a eles 


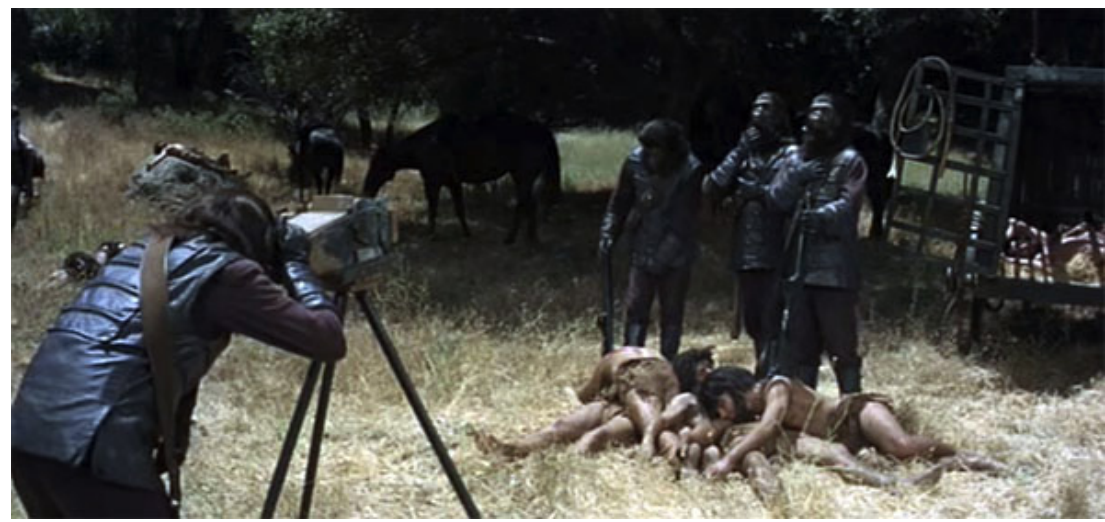

o tempo necessário, chegará o momento em que sejam capazes de empunhar uma câmera e tirar fotos. Quando isso acontecerá? Depende. Segundo Pierre Boulle, há evidências de que isso acontecerá no século XL da nossa era, exatamente no ano 3978. Nesses tempos, a civilização será autoimolada depois de uma definitiva guerra nuclear e só sobrevivem poucos grupos de humanos no estado selvagem. Em vingança, uma nova ordem de gorilas, melhor adaptados às sequelas devastadoras da radioatividade, toma o controle do planeta. Como fazem todas as espécies dominantes, os gorilas se dedicam a exterminar as espécies consideradas inferiores, nesse caso, os humanos, que apesar de terem sofrido uma evolução regressiva, são considerados uma ameaça.

Evidentemente se trata de uma alusão ao Planeta dos Macacos, o romance premonitório que Boulle publicou em 1963 e que, em 1968, foi levado ao cinema com Charlon Heston de protagonista. 0 filme, com um script que tomou muitas liberdades em relação ao texto original, se tornou um grande sucesso popular, o que incentivou a indústria do espetáculo a gerar todos os tipos de franquia ao seu redor, com remakes, adaptações, séries de televisão e quadrinhos. A história se centra na aventura do astronauta George Taylor, cuja nave é lançada ao espaço em 1972, mas, viajando na velocidade da luz, sofre um acidente e resulta que, quando regressa à Terra, milhares de anos se passaram. Ao sair da cápsula se encontra com um grupo de humanos de aparência pré-histórica (carentes de fala, vestidos com tangas de pele), que fogem apavorados porque uma patrulha de gorilas uniformizados, montados a cavalo e armados com rifles, está realizando uma busca para caçá-los. Os humanos são massacrados e os poucos sobreviventes, enjaulados. Taylor, que foi baleado na garganta, o que o deixou sem voz e, portanto, sem a possibilidade de proclamar que "ele não é um animal", assiste alucinado a esse safári sangrento. Um safári que termina com a cena de costume: frente ao amontoamento das presas recolhidas, os caçadores fazem uma foto triunfal. É o seu troféu: um clichê iconográfico que migrou das 
planícies da África e do grande caçador branco, para as atrocidades de Abu Ghraib e do Estado Islâmico.

De fato, a ficção cinematográfica já havia antecipado, na sua fase pioneira, a figura do macaco fotógrafo. Em 1928, Buster Keaton protagonizou The Cameraman, interpretando um operador de câmera na tentativa de mostrar seu valor profissional e seduzir uma moça. Seu animal de estimação é um inteligente babuíno que Ihe deu maliciosamente um organista de rua. Em uma das cenas finais a moça sofre um acidente em uma competição de barco e está quase morrendo afogada quando o

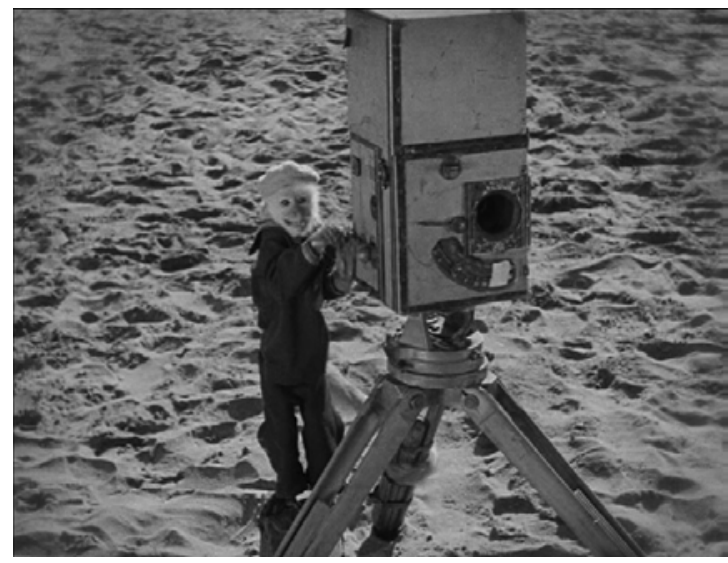
protagonista se lança ao mar com valentia e a salva.

Coloca-a inconsciente na praia e corre para buscar socorro e medicamentos, momento em que um outro pretendente aproveita para simular ter sido o salvador. Porém, o macaco havia registrado toda a ação como um cameraman profissional e quando a fita é assistida se descobre a identidade do verdadeiro herói. A suposta surpresa, claro, foi que uns movimentos de câmera, majestosos e superelaborados, tivessem sido rodados mecanicamente por um macaco com uma câmera ultrapassada.

Casualmente (ou não), em 1928 outro filme com um título quase idêntido foi rodado - Um homem com uma câmera - e de tendência semelhante: na União Soviética, Chelovek s kino-apparatom (Dziga Vertov) é outra obra-prima que faz do cameraman um heroi que trabalha sem se importar com esforços ou perigos. Para Juan Barja, ambos os filmes expoem

[...] a consumação da desubjetivação da imagem: a câmera é utilizada sozinha em uma demonstração do poder do truque que entusiasma o público. Por outro lado, a celebração das façanhas da câmera coexiste com o tema do domínio do homem sobre os objetos fabricados pela máquina. ${ }^{1}$

A visão técnica, fortuita e não intencional prevalece sobre a subjetividade. Para as vanguardas era a aceitação do olhar da máquina - ou do animal, quer dizer, do não humano - o que redime o homem de seus atavismos e de duas rotinas: a irracionalidade, ou seu âmago, é o recurso para alcançar uma nova racionalidade.

Certamente que essa troca de olhares foi o que seduziu no projeto do fotógrafo da imprensa alemã Hilmar Pabel, que trabalhava como freelance para o Berliner Illustrierte Zeitung, uma das bases que propiciaram a consolidação do novo fotojornalismo na República de Weimar. Em 1935, Pabel teve a ideia de propor emprestar Leicas aos chimpanzés do zoológico de Berlim, e pedir a seus cuidadores que os adestrassem a apertar o obturador, imitando

1. Juan Barja, Atlas Walter Benjamin Constelaciones, Círculo de Bellas Artes, Madrid, 2010. 
o gesto dos visitantes, adultos e crianças, que não paravam de fotografar, com suas próprias câmeras, as andanças dos macacos. 0 modelo virou fotógrafo. Os editores ficaram encantados e publicaram os resultados da performance. Mas quando Pabel apresentou o projeto, se desapontou: com que direito pretendia cobrar fotos que não havia feito? Os verdadeiros autores eram os chimpanzés. Não serviu de nada argumentar que foi ele quem orquestrou a situação e que tanto faz quem havia disparado a câmera: o que realmente importava era como o projeto se carregava de sentido. Pabel perdeu essa batalha, mas não a guerra: renegociou a reportagem com a Life, que a publicou em 5 de setembro de 1938, com sua autoria reconhecida. Circunstância à parte, esse caso exemplifica a situação da condição autoral, não tanto no fazer como no prescrever, ou seja, na atribuição de valor e sentido, na conceitualização, a qual adquire relevância maior no contexto da internet. Em 1888, George Eastman cunhou aquele famoso slogan que levou a Kodak para o topo da indústria fotográfica ("você aperta o botão, nós faremos o resto"); hoje nos damos conta que o importante não é quem aperta o botão e sim quem faz o resto: quem coloca o conceito e administra a vida da imagem.

\section{IMAGENS QUE BOCEJAM (IMAGENSZZZZZZ)}
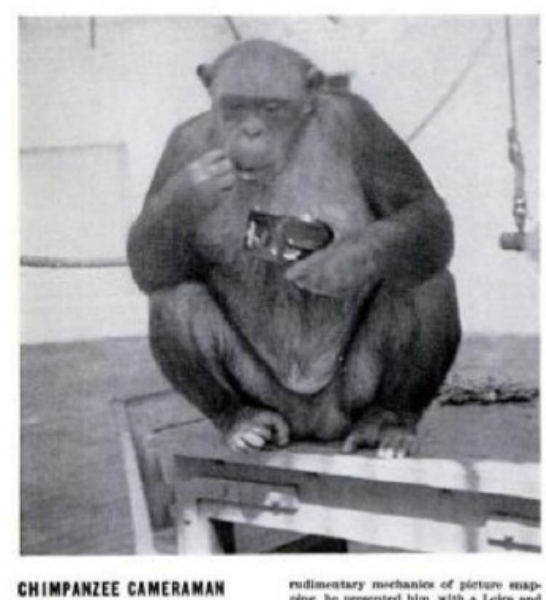

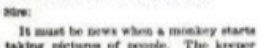

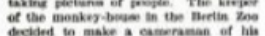

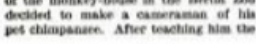

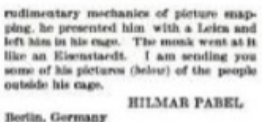

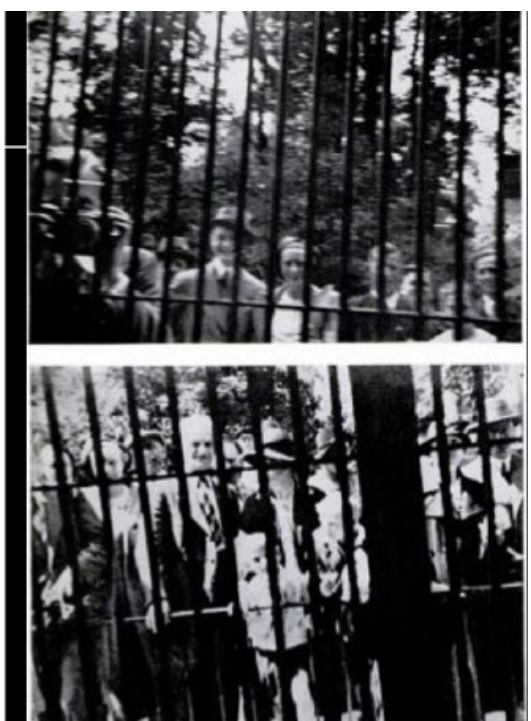

As derivações filosóficas do caso de Pabel apenas multiplicaram-se na era pós-fotográfica, que iniciaria determinada pela preeminência da internet, das redes sociais e da telefonia móvel. Consideremos o estudo de caso a seguir. Em 2011 o fotógrafo naturalista britânico David Slater se encontrava na ilha de 

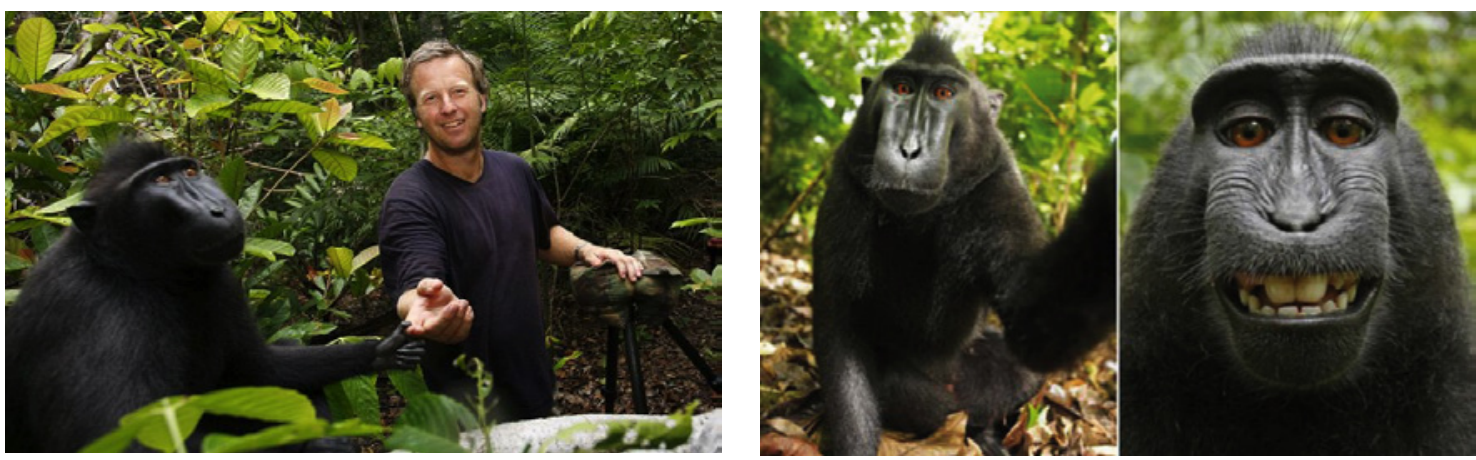

Sulawesi, realizando uma reportagem com um bando de macacos-de-crista-negra (Macaca nigra). Slater se deu conta que em um determinado momento uma fêmea adulta se aproximava da sua câmera montada em um tripé, descobrindo extasiada seu próprio reflexo na lente. Começou, então, a manuseá-la pressionando casualmente o botão do obturador. 0 resultado desse feliz acidente foram vários autorretratos que fascinaram Slater. A primeira selfie feita por um macaco ocupou muitas capas e se tornou viral nas redes. As imagens se tornaram tão populares que a Wikipedia decidiu utilizar uma para ilustrar sua entrada Celebes crested macaque [Macaca nigra]. Slater se sentiu prejudicado pela reprodução não autorizada e exigiu sua retirada. A Wikipedia argumentou que se tratava de uma fotografia obtida por um animal e, portanto, pertencia ao domínio público. A disputa acabou nos tribunais. Em agosto de 2014, o US Copyright Office emitiu uma deliciosa sentença de 1222 páginas em que, de forma explícita, excluía a possibilidade de atribuir direitos de autor a qualquer obra criada pela "natureza, animais, plantas, seres divinos e sobrenaturais". Ou seja, nem a natureza, nem Deus, nem os fantasmas tem o direito para reclamar copyright: os direitos de autor estão reservados a obras criadas por humanos.

O importante, no entanto, é que por trás da anedota encontra-se um debate sobre as conexões entre a autoria, a criação e a nossa condição humana. Rebobinemos. Por ora, a excepcionalidade da foto deriva de que aceitemos a versão que Slater nos dá: ou seja, que a foto foi tirada pelo macaco. ${ }^{2}$ Concordaríamos que se se tratasse de um retrato realizado simplesmente pelo fotógrafo, desaparecia o equívoco sobre a autoria ao mesmo tempo que o interesse em fazer. Vejamos, então, que nessa história os dois fatos mais marcantes são também os mais duvidosos. Um é que se quem fez o clic fosse um macaco; a câmera poderia ter sido disparada por qualquer golpe fortuito, inclusive poderia ter sido acionada de forma involuntária por qualquer outra pessoa diferente de Slater. Para efeitos teóricos, o que importa é a falta de intenção. 0 segundo elemento duvidoso é o julgamento, porque não representa apenas a aplicação

2. Também poderia ser uma invenção, mas a verdade é que agora Slater é um prisioneiro de sua história. 


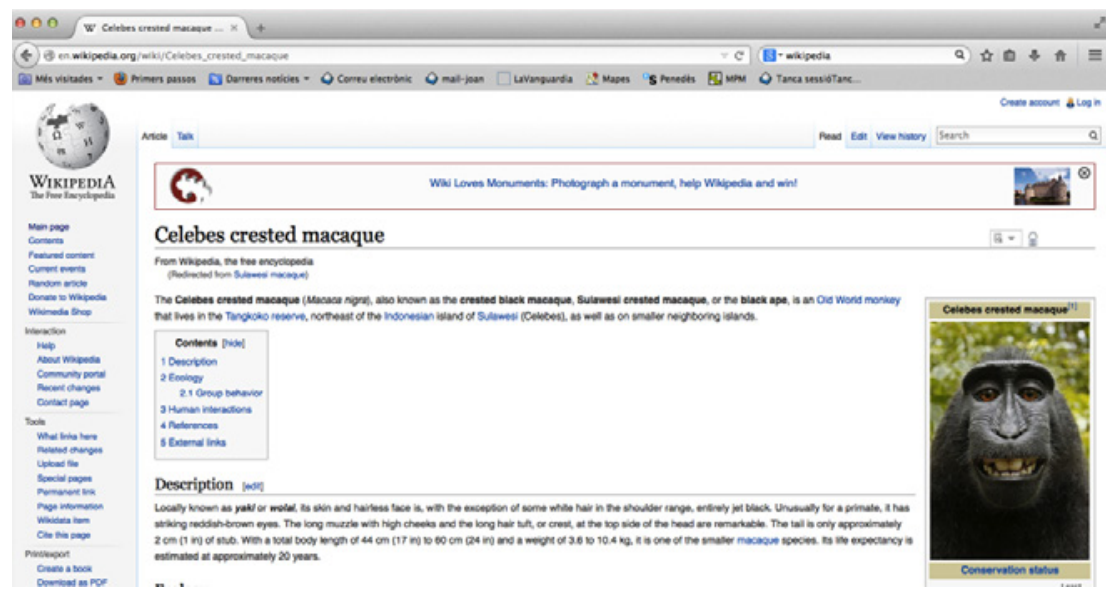

de regras de jogo válidas para um tempo e um lugar. A lei da Grã-Bretanha, por exemplo, teria resolvido o caso de forma diferente porque de acordo com a Copyright Designs and Patents Act, de 1988, os fotógrafos podem reivindicar direitos sobre uma imagem que possa ser considerada sua "criação intelectual" (por exemplo, se articulamos o conceito de um macaco fazendo uma selfie), ou se organizam uma situação e fornecem os meios para que uma imagem seja produzida (por exemplo, se instalo uma câmera de vigilância em um determinado lugar, posso reclamar os direitos sobre os fotogramas obtidos).

Em contraposição se destacam dois fatos significativos. $O$ primeiro é que, diferentemente das câmeras do século XIX, o equipamento utilizado por Slater era um dispositivo portado de um complexo programa integrado que atuava por parâmetros padrões (frame, foco automático, exposição automática, processamento de captura, codificação de metadados, etc.). Tal programa pode ser entendido como um pacote de conhecimentos comprimidos e aplicados para produzir um determinado tipo de representação pictórica: aos necessários desempenhos mecânicos e ópticos, as câmeras atuais integram um modelo de engenharia eletrônica e performance informática que faz de seus sofisticados automatismos o fermento da robotização. A câmera se torna o apoio de uma inteligência tecnológica autônoma. Quando o macaco pressionou - inocentemente - o botão da câmera, acionou toda a cadeia de valores ideológicos - nada inocentes - inerentes à história da representação realista, desde a techné helênica e a perspectiva central renascentista até o naturalismo positivista e o êxtase escópico das sociedades do capitalismo tardio.

O segundo elemento significativo reside no ato de apropriação por parte do fotógrafo. Até esse momento só tínhamos uma imagem adormecida, conseguida por um agente involuntário. Uma imagem que repousava no limbo do cartão de 
memória, como Branca de Neve no bosque à espera do beijo que lhe devolva à vida. Slater foi o oportuno príncipe encantado que deu esse beijo: insuflou intenção a uma imagem que carecia dela. Identificou essas tomadas singulares, as editou, geriu sua mise-en-valeur, promoveu sua visibilidade e organizou sua circulação. Em outras palavras, acrescentou sentido a elas. De uma imagem bruta e não obra, Slater fez uma obra. A mera imagem foi fabricada em cooperação pelo corpo do macaco e os automatismos da câmera; a imagem-obra foi criada por Slater ao prescrever sentido. E daí se infere que o raciocínio permanece válido para todas as imagens que dormem, então em mercados de pulgas, em arquivos ou em qualquer dos meandros da rede.

\section{O HUMANISMO COMO ANTÍDOTO}

Se repassarmos todas essas considerações, chegamos à seguinte cadeia dedutiva: para que haja criação que culmine em uma obra, é necessário intenção; para que haja intenção é necessário vontade; para que haja vontade é necessário consciência; e para que haja consciência, é necessário humanidade. Consequentemente, quando a pós-fotografia problematiza a autoria, não interpela tanto a teoria estética quanto a filosofia da consciência e da condição humana. A consciência é ainda uma prerrogativa humana? É pensável, hoje, uma consciência das máquinas? A ficção científica e a literatura cyberpunk já fizeram desse argumento especulativo um de seus mais apaixonantes filões. Mas quando nos voltamos ao pensamento contemporâneo, assomam igualmente valiosas vias de reflexão; centremo-nos no humanismo digital, formulado entre outros por Milad Doueihi, que se opõe ao singularitarianismo de teóricos como Eliezer Yudkowsky e Ray Kurzweil. Consiste em afirmar que a tecnologia digital, em sua dimensão global, excede o âmbito da técnica e se converte em uma cultura: uma cultura que inaugura uma nova civilização e que se caracteriza, ao contrário dos humanismos "aristocráticos" que nos precedem, por fomentar o intercâmbio de todos os conhecimentos. Sua essência é, antes de mais nada, compartilhar, e esta ideia de repartir incumbe, inexoravelmente, o social e o político. 0 digital consagra um novo espaço entre o real e o virtual, entre o concreto e o imaginário, e nesse espaço híbrido se sobressai uma nova maneira de fazer comunidade. 0 reverso da moeda é que essa cultura deve enfrentar um conflito: o da liberdade do indivíduo.

Essa dimensão, simultaneamente existencial e filosófica, concerne a transformação do humano em um objeto digital, mas também em um objeto do digital, ou seja, em um ser cultural digital, convertível, extensível e capaz de circular de modos inéditos graças à convergência da tecnologia com o corpo. Por esta razão, o humanismo digital só pode dialogar com os discursos transumanistas. ${ }^{3}$

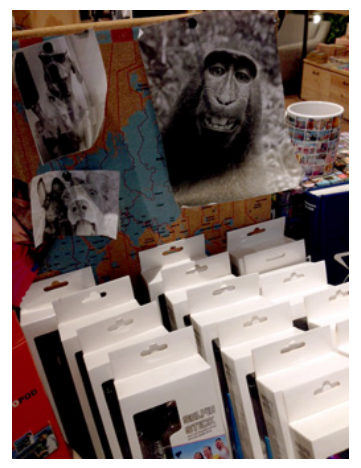


4. Ray Kurzweil, The age of intelligent machines, MIT Press, Cambridge, 1990, e The age of spiritual machines: when computers exceed human intelligence, Penguin Books, New York, 1999.
Tais discursos transumanistas geralmente são sujeitos à Teoria da Singularidade, que prevê a chegada, como o esperado messias ou o temido golem, de uma singularidade tecnológica: a criação de superinteligências artificiais benéficas (supostamente) para a humanidade. Pouco a pouco vamos convergindo com a inteligência artificial e cada vez nos custa mais distinguir nossa mente de suas próteses: os GPS, os smartphones e todo o tipo de computadores... As máquinas, por outro lado, estão se tornando independentes de nós e cada vez interagem mais entre elas sem nossa mediação, de forma que adquirem sua própria autonomia. Os gurus singularitarianistas preveem que nos dissolveremos nas máquinas e que sentiremos e pensaremos como elas. Já é previsível que em um futuro próximo as máquinas adquiram emoção e tornem-se "espirituais". ${ }^{4}$ Nesse panorama que linda com o místico, o mais preocupante, adverte Doueihi, é que a inteligência artificial é capaz de gerir memória melhor que os humanos, mas só é capaz de geri-la, não de gerá-la. E se a máquina não pode ter memória, tampouco pode ter identidade: essa seria sua limitação e, de uma perspectiva religiosa, sua condenação.

Nessa encruzilhada, como se posiciona a fotografia, quando paradoxalmente seu mandato histórico tem sido o de salvaguardar a identidade e a memória? A câmera tem servido como ortopedia da memória biológica, uma função que agora está suprindo, sobretudo, a memória maquínica. Se a cultura digital transforma o humano, é essencialmente na sua maneira de condicionar nossas relações com a memória, fazendo-nos acreditar que a memória equivale ao simples acesso à informação ou a uma forma de disponibilidade dos dados. Mas a experiência do passado está sempre submetida a uma perspectiva de interpretação, ou seja, a uma interface, que nunca é neutra nem inocente. Para que essa interface seja eficiente temos que estar dotados da faculdade de esquecimento, e as máquinas não esquecem: somente apagam. Para inovar e evolucionar, para ver o mundo de forma diferente, faz falta poder e saber esquecer. 0 esquecimento é, portanto, um preâmbulo necessário para o humanismo digital - talvez em sintonia com a indiferença que mostra a pós fotografia com a função mnemotécnica e a responsabilidade de recordar. Se a primeira revolução digital levou ao descrédito de um determinado regime de verdade, com a segunda é a vez da memória.

Nesse horizonte, ainda confusos pela dissolução da verdade e da memória, temos que agradecer que selfies como a do macaco da Slater nos ajudem a entender a pós-fotografia como uma prática que aproveita a imaginação dominada pela propaganda, pela indústria da mídia e pelo consumo. A avalanche de imagens seguirá nos avassalando e talvez em breve consideremos manejar câmeras espirituais - ainda que, quem sabe, se manejarão por si sós ou nos manejarão, ou nos fundiremos em um manejo conjunto. E nos perguntaremos se 
estes cenários são desejáveis. E é aqui onde a pós-fotografia nos aparece como um corpus crítico para tratar dessas questões, definir o horizonte em que desejamos nos instalar ou preparar antídotos para os perigos que tentamos evitar.

\section{Joan Fontcuberta}

Joan Fontcuberta (Barcelona, 1955) desenvolve múltiplas atividades no mundo da fotografia como criador, docente, crítico, curador de exposições e historiador. Professor visitante em universidades na França, Grã-Bretanha e Estados Unidos. Colabora sistematicamente em publicações especializadas. Em 2013 foi contemplado com o Prêmio Hasselblad de fotografia. 
